\title{
Before the Law: Limits, Malice and The Immortal Hulk
}

\author{
Neal Curtis \\ The University of Auckland, New Zealand
}

\begin{abstract}
This article uses Kafka's short story 'Before the Law' to offer a reading of Al Ewing's The Immortal Hulk. This is in turn used to explore our desire to encounter the Law understood as a form of completeness. The article differentiates between 'the Law' as completeness or limitlessness and 'the law' understood as limitation. The article also examines this desire to experience completeness or limitlessness in the work of George Bataille who argued such an experience was the path to sovereignty. In response it also considers Francois Flahault's critique of Bataille who argued Bataille failed to understand limitlessness is split between a 'good infinite' and a 'bad infinite', and that it is only the latter that can ultimately satisfy us. The article then proposes The Hulk, especially as presented in Al Ewing's The Immortal Hulk, is a study in where our desire for limitlessness can take us. Ultimately it proposes we turn ourselves away from the Law and towards the law that preserves and protects our incompleteness.
\end{abstract}

Keywords: Law; sovereignty; comics; superheroes; The Hulk

\section{Introduction}

From Jean Bodin to Carl Schmitt, the foundation of the law, or what we more readily understand as sovereignty, is marked by a significant division. The law is a limit in the sense of determining what is permitted and what is proscribed, but the authority for this limit is often said to derive from something unlimited. Conservative philosophers tend to conceive of this supra-legal entity in the person of the monarch, the divine will of God or the instantiation of the Good. Alternatively, radical philosophers think of it as an indeterminate "constituent power" ${ }^{\text {' }}$ or a "radical imaginary" rooted in human freedom. However, for conservative thinkers like Schmitt, this radical conception of freedom is a path to potential (inevitable) disorder, a condition from which sovereignty ought to protect us. Thus, in their conjuring of an unlimited Good they often channel an unlimited Evil — something like the Good's dark shadow - that is said to threaten the unitary order of the state. Over the course of our short century, this conservative, particularly Schmittian vision of the law has become dominant. It was especially evident in the logic of the war on terror, in which world-destroying monsters were evoked as a justification for throwing off any legal limit in defence of the Good. This battle against evil also became a path for self-completion, as the United States supposedly fulfilled its divine mission. In Schmitt's own time his desire for order founded on something 'analogous to the miracle in theology' ${ }^{3}$ saw him evoke visions of total dissolution and assume an utterly monstrous political allegiance.

Outside of philosophical meditations on the law and sovereignty, popular culture is replete with stories of protagonists achieving some form of self-completion through an engagement or confrontation with an entity deemed all powerful and absolutely evil. Elsewhere, I have argued at length that superheroes are especially useful for exploring these issues. ${ }^{4}$ Rather than being mere vigilantes operating outside the law, their power encapsulates the sovereign's ability to cast off legal limits or suspend the law in the face of an emergency occasioned by an existential threat. In this sense, these stories often set the absolute goodness of Superman or Captain America against the absolute evil of Darkseid or Thanos. Sometimes these characters are explicit allegories for our own desire to exist without limit or encounter limitlessness. Exemplary in this regard is The Hulk. As the

\footnotetext{
${ }^{1}$ Negri, Insurgencies, 7.

${ }^{2}$ Castoriadis, Imaginary Institution of Society, 370.

${ }^{3}$ Schmitt, Political Theology, 36.

${ }^{4}$ Curtis, Sovereignty and Superheroes.
}

Except where otherwise noted, content in this journal is licensed under a Creative Commons Attribution 4.0 International Licence. As an open access journal, articles are free to use with proper attribution. ISSN: 2652-4074 (Online) 
alter ego of physicist Dr Bruce Banner-created during experiments with a totally destructive technology called the Gamma Bomb - he is the monstrous product of our desire for limitless power. Thus, The Hulk is both Prometheus and Frankenstein's monster. He is a tragic reminder of what can happen when we seek to claim what is divine.

In what follows, I will argue that Al Ewing's current run on the comic, The Immortal Hulk, is an especially interesting study of both the monster and sovereignty, where sovereignty is understood as the relationship between the law defined as a set of rules or norm-based limits and the Law conceived as the limitlessness that founds and authorises them. The story is analysed using the work of François Flahault, as set out in Malice (2003), to explain what is potentially so dangerous about this relationship and our desire to seek completion in limitlessness. Against this desire for limitlessness, I finally argue that the collective of personalities within The Hulk and his association with other members of the gamma-irradiated 'family' tempers his most destructive tendencies. This 'family' intimates a politics in which the mundane workings of the law protects and facilitates the association of otherwise incomplete beings in what we call society. It is this that guards against the most destructive aspects of The Hulk's limitless power. However, before turning to Flahault, I would like to revisit an old story about our desire to encounter the Law that introduces some key themes as well as the central metaphor in Ewing's story.

\section{Before the Law}

In Franz Kafka's short story 'Before the Law' —also recounted to K. in Kafka's The Trial—we learn about a man from the country whose access to the Law is blocked by a doorkeeper who says he cannot grant him access. Instead, the doorkeeper asks him to sit on a stool next to the door and wait. The man waits there for 'days and years' ${ }^{5}$ offering the doorkeeper bribes to gain access, which the doorkeeper accepts, but he never lets him in. The man stays there for the remainder of his life until he finally asks why no-one else has come to ask for access to the Law. At this point, with the man from the country approaching death, the doorkeeper tells him, "no one but you could gain admittance through this door, since this door was intended only for you. I am now going to shut it." ${ }^{6}$ That is the end of the story and the end of the man's life.

Interpretations of the story tend to accord with readings of other works by Kafka in which the anonymity and distance of the Law is explored. For example, James Martel talks of the story as an allegory for the deferral of justice. For him, this is the reason the Law is capitalised because it represents the fullness of the Law as a final access to and delivery of justice. ${ }^{7}$ The point, of course, is that achieving such fullness is a permanent expectation and one that the law can never fully satisfy. It can also be read as a story about the separation of the Law understood as that which is sovereign. For example, in the work of Jean-Luc Nancy, the absolute nature of sovereignty places it beyond the relativity of things. ${ }^{8}$ There literally can be no relation to sovereignty because relation is precisely what it precludes. For Martel, Kafka reminds us that all we can ever hope for is a relationship with the Law's agents and officials as the embodiment of an authority no-one can see. He writes, 'Kafka's parable invites us to think about what the law (in its ordinary "small $l$ " sense) is when it is not connected to the Law, when it is experienced only in its banal ordinariness, its day-to-day mediocrity'.

But what exactly is behind the door? Kafka is clear that we do not and can never know. In his commentary on the story, Jacques Derrida writes:

the law is silent, and of it nothing is said to us. Nothing, only its name, its common name and nothing else. ... We do not know what it is, who it is, where it is. Is it a thing, a person, a discourse, a voice, a document, or simply a nothing that inescapably defers access to itself? ${ }^{10}$

Our only sense of what lies behind the door is the doorkeeper's warning to the man that he is only the first of the doorkeepers: 'From hall to hall', says the first doorkeeper, 'keepers stand at every door, one more powerful than the other. Even the third of these has an aspect that even I cannot bear to look at.' ${ }^{11}$ There is the suggestion, then, of something awful or terrifying in the presence of the third doorkeeper. It also asks us to imagine the dread, even horror that might be felt in the presence of the fourth or fifth doorkeepers, let alone those that come after. It can only be presumed that should the man cross the threshold the experience will be ever more unbearable as he approaches the Law. In this sense, the doorkeeper is not just guarding the Law from the man: he is also guarding the man from the Law. Yet, again, what is the Law here? The only other clue to what lies beyond the threshold occurs close to the man's death. Here, his eyesight begins to fail and the world becomes darker, but 'in

\footnotetext{
${ }^{5}$ Kafka, Complete Novels, 186.

${ }^{6}$ Kafka, Complete Novels, 187.

${ }^{7}$ Martel, "Waiting for Justice," 159.

${ }^{8}$ Nancy, Creation of the World, 97.

${ }^{9}$ Martel, "Waiting for Justice," 159.

${ }^{10}$ Derrida, "Before the Law," 208.

${ }^{11}$ Kafka, Complete Novels, 185.
} 
the darkness he can now perceive a radiance that streams immortally from the door of the Law'. ${ }^{12}$ The Law seems to have the radiance of a sun that illuminates the scene of his waiting as it gradually descends into shadow. The light is without limit, as the man has the only encounter he can have, particularly with his own finitude.

The radiance of the Law, as well as its capitalisation, suggests the man does indeed wish to encounter God or sovereignty, and yet, as I have suggested, the absolute nature of sovereignty means it is pure self-relation. More importantly, if sovereignty is ultimately defined by this lack of a relation to anything else, sovereignty cannot be thought in terms of the relativity of entities, beings or things. This poses the problem that sovereignty properly understood as that which is absolute, and absolutely powerful, must also be thought of as no thing, nothing - a void, limitlessness. Alternatively, we might think of it as a selfconstituting origin that is, in turn, the limitless source of all that is. From this perspective, 'Before the Law' tells a story of the desire for a limited being to touch and seek completion (satisfaction, fulfilment) in limitlessness. What is important for my reading here, though, is that this limitlessness is not only the perfect One of self-creation, but also the chaotic Nought of formlessness. Hence, the Law is an alloy of two countervailing principles, and, as noted, a dark shadow accompanies our desire to encounter it.

\section{On Limits and Limitlessness}

For Georges Bataille it is the law, or more specifically the prohibitions and interdictions the law sets out, that separate humans from animals. It is that which partitions the sacred from the profane and sets out the rules regulating this division. However, while it is the law that makes us who we are, there remains a desire to cross these limits and in doing so experience limitlessness or 'sovereignty without partition'. ${ }^{13}$ In Bataille's cosmology, the problem arises from the 'fact' that all individuals-or 'discontinuous beings' - emerge out of cosmological continuity, and humans desire to retouch this continuity and experience the immediacy of living 'like water in water'. ${ }^{14}$ For Bataille, this desire to encounter and lose oneself in continuity, limitlessness or the infinite is the origin of religious experience and is precisely what the man from the country was seeking in his approach before the Law.

According to Bataille, one way to experience continuity is through practices of transgression that overcome legal regulations and the original partition between sacred and profane. Such 'sovereign' practices, as he called them, invariably involve a brush with death because death alone can reveal the 'invisible brilliance of life that is not a thing'. ${ }^{15}$ The qualification, of course, is that this must be an encounter with death in which death is not the victor. What we desire, then, is not to die but through an encounter with death 'bring into a world founded on discontinuity all the continuity such a world can sustain'. ${ }^{16}$ The writer most sensitive to the implications of this desire to touch limitlessness - or, in the terminology of this paper, to encounter the Law - is François Flahault. In his book, Malice, he carefully opens up a problem that Bataille did not see, notably that our conceptualisation of continuity or limitlessness is split between the ideal and the demonic — or, as I noted, in relation to the sovereign nothing, a perfect One and a chaotic Nought.

In other words, Flahault argues that we differentiate between 'an infinite which is tamed, harnessed and made palatable', ${ }^{17}$ ordinarily understood as the God we know and who created us, which Flahault calls the 'good infinite', and a 'radical limitlessness [that] is made manifest ... in the void of a bottomless well and the nightmare of destruction', which he calls the 'bad infinite'. ${ }^{18}$ However, it is also essential to note that because being and the world of divine creation are associated with the distinction, demarcation and finitude of individual beings, 'it is only non-being which exists absolutely or infinitely' ${ }^{19}$ In other words, the tamed or good infinite does not ultimately satisfy our desire for an encounter with limitlessness, only the wild, destructive bad infinite that threatens everything provides the desired satisfaction. I would suggest the doorkeeper knew this and did a great service to the man from the country in not letting him in. We might say that the law separates us from the Law for our own good.

The tendency to seek out the radical limitlessness of the bad infinite is what Flahault calls our 'abyssal narcissism' ${ }^{20}$ It is the psychological impulse through which our desire to touch limitlessness is expressed. The superhero genre is, of course, a playground for our 'abyssal narcissism', with creators outdoing each other in their efforts to conjure the most destructive,

\footnotetext{
${ }^{12}$ Kafka, Complete Novels, 186.

${ }^{13}$ Bataille, Inner Experience, 5.

${ }^{14}$ Bataille, Theory of Religion, 24.

15 Bataille, Theory of Religion, 47.

${ }^{16}$ Bataille, Eroticism, 19.

${ }^{17}$ Flahault, Malice, 7.

${ }^{18}$ Flahault, Malice, 7.

${ }^{19}$ Flahault, Malice, 22.

${ }^{20}$ Flahault, Malice, 8.
} 
universe-destroying (even omniverse-destroying) monsters. In the DC Universe we have the cosmic fascist known as Darkseid who is epitomised by his use of the Anti-Life Equation in Final Crisis, ${ }^{21}$ but even more powerful than him is the Anti-Monitor, who is effectively sovereign of the antimatter universe with the capacity to wipe out existence should the realms of matter and antimatter collide. ${ }^{22}$ In the Marvel Universe, a particular favourite is Amatsu-Mikaboshi, or the Chaos King, who has the power to void or nullify anything, but the most important figure is probably Galactus the World-Eater (formerly Galan of Taa). This vision of radical limitlessness first appeared in Fantastic Four \#48 from 1966, ${ }^{23}$ but his origin story was not finalised until Super-Villain Classics \#1 from 1983. ${ }^{24}$ Reworking material mostly taken for Thor comics published in 1969, Galactus is effectively the origin of our universe, being the only entity - thanks to an intervention by the Sentience of the Universe-to have survived the end of the universe that existed prior to our big bang. While Galactus represents a pre-monotheistic duality, asking, 'am I merely an agent of disorder and destruction? No, the power cosmic can be wielded for any purpose-creation as well as annihilation, ${ }^{25}$ he commits his creativity to the construction of his worldship, Taa II, a feat that requires him to consume planets to maintain his energy. It is in this radically limitless mode of 'world-eater' that he is best known.

Before revisiting Galactus, let us return to Flahault and the desire to engage with the radical limitlessness of evil, which does not actually represent a desire to be rid of it so much as a desire to remain alongside it. In Malice, Flahault documents his own childhood flirtation with monsters. He remembers going into the cellar of his family home only to become aware of some lurking malevolence in the looming darkness; rather than taking this dark presence to be the manifestation of some independent and evil force, he came to understand that the monster 'owed its presence to [his] imagination' ${ }^{26}$ It appeared only because 'a whiff of non-being ... had spurted out of [him]'. ${ }^{27}$ Thus, the monster represented his own desire to face the bad infinite and touch radical limitlessness. Developing Freud's argument regarding the primary narcissism of a newborn infant who has no sense of self and no sense of distinction between an inside and an outside, a subject and a world of objects, Flahault writes, 'the inborn self, the initial self, is not self, but a kind of non-bounded, non-differentiated proto-subjectivity'. ${ }^{28}$ To become a subject, with a name and a place in the world, it is necessary to give up 'this infinite self, which precedes the defined self, just as primordial Chaos precedes the differentiated world' ${ }^{29}$ In keeping with Bataille's argument regarding our desire for intimacy, we are split between an 'inborn boundlessness ${ }^{30}$ and the limited, bounded requirements of social existence protected by the law, and yet we always desire to return to the original state of being without limits. It is this compulsion to conjure monsters and the violence that is required to defeat them that becomes Flahault's ultimate concern.

Perhaps the most important and disturbing insight of Flahault's work is his observation that our desire to encounter sovereignty or the Law is achieved 'through the exhilarating sense of attaining a superior finality, which derives from the felt need to compete with the limitlessness which has been projected on to the other' ${ }^{31}$ the greater the threat of dissolution, the greater the sense of completion. (Again, so much of the conservative literature on the war on terror supports this formulation.) Stated even more starkly:

the need to struggle against Chaos, far from being expressed in the building of some fundamental barrier capable of resisting it, is presented as the need to confront it, to enter into a relation with it in order to counter it with a remedy comparable with the evil, a means of pacification which responds to its voracity. ${ }^{32}$

In such a situation, the 'struggle against Chaos' becomes indistinguishable from 'the pleasure of plunging into it' ${ }^{33}$ —and this could easily be the tagline for The Hulk as avenger and breaker of worlds.

To situate this troubling desire alongside legal theory, it is helpful to consider a short essay by Richard John Neuhaus who, in the long tradition of conservative Catholic jurisprudence that includes the work of Carl Schmitt, articulates the need to derive the law from something beyond it that he calls the good (or the Law in the idiom of this paper). He argues 'it is without meaning to speak of morally legitimate law except by reference to the good from which it is begotten and to which it is accountable'. ${ }^{34}$

\footnotetext{
${ }^{21}$ Morrison, Final Crisis.

22 Pérez, Crisis on Infinite Earths.

${ }^{23}$ Lee, Fantastic Four.

${ }^{24}$ Lee, Super-Villain.

${ }^{25}$ Lee, Super-Villain.

${ }^{26}$ Flahault, Malice, 40.

${ }^{27}$ Flahault, Malice, 40.

${ }^{28}$ Flahault, Malice, 41.

${ }^{29}$ Flahault, Malice, 41.

${ }^{30}$ Flahault, Malice, 42.

${ }^{31}$ Flahault, Malice, 50.

${ }^{32}$ Flahault, Malice, 132.

${ }^{33}$ Flahault, Malice, 131.

${ }^{34}$ Neuhaus, "Nihilism," 53.
} 
The source of law can, therefore, only be something that transcends it. For Neuhaus, like Schmitt, this is a religious source. Law, he claims, 'is not law unto itself. Law unto itself is no law at all. This is obviously true in the everyday workings of society. A person who is a law unto himself is an outlaw. ${ }^{35}$ However, just as Schmitt argued, sovereign legitimacy arises from theological principles that lie beyond the realm of mundane legality, so Neuhaus also appeals to religion for the universality of the good. For him, 'universality means more than the validity bestowed by the procedures of a society. If the law of a society does not transcend that society, then that society, including its legal procedures, is an outlaw. ${ }^{36}$ It is precisely this transcendent universality that the man from the country seeks.

Neuhaus goes on to say that having lost this idea of transcendent universality - this good that is really God-is how 'we have arrived at the abyss' ${ }^{37}$ For him, a law that lacks a 'public account of the good' 38 has no legitimacy, and without legitimacy it is not truly law, just the nihilistic relativism of majority opinion-an issue that was also of concern to Schmitt. ${ }^{39}$ However, Neuhaus is not entirely anti-democratic. He does recognise his good cannot be unitary even if it must be universal. Reconnecting with a notion of a transcendent good, therefore, opens up a path to what he calls 'nihilism without the abyss' ${ }^{40} \mathrm{He}$ believes the law must rediscover its source of legitimacy, but warns that:

publicly assertive religious forces will have to learn that the remedy for the naked public square is not naked religion in public. They will have to develop a mediating language by which ultimate truths can be related to the penultimate and prepenultimate questions of political and legal contest. ${ }^{41}$

However, what is intriguing about his invocation of a transcendent good (the good infinite) is that he cannot do so without also conjuring images of dissolution (the bad infinite). Without recovering the Law that properly legitimises the law, he sees only two alternatives: 'One alternative is open-ended and religiously-impassioned civil warfare. Another alternative is to resign ourselves to the fact that the barbarians have triumphed. ${ }^{42}$ It is, then, the dark shadow that accompanies this invocation of the Good or the Law that I find so troubling. As noted, for Schmitt, the threat from a legal system not rooted in a transcendent universality led him to struggle against it, and by joining the National Socialist Party in 1933 he plunged into the very chaos he hoped to guard against. In the character and comic I have chosen to study, the question for me is how does it illustrate both this problematic desire and a solution to it.

\section{The Hulk as Prometheus}

More than any other character, The Hulk represents this human capacity to plunge into the bad infinite. When Stan Lee and Jack Kirby created him in 1962 he represented a broad cultural concern about nuclear power and nuclear bombs in particular. ${ }^{43}$ In an age of mutually assured destruction, a range of Silver Age superheroes were transformed and given powers by various types of radiation, from the Fantastic Four, to Spider-Man, to Daredevil, but it was The Hulk and his alter ego, Bruce Banner, that came to literally embody the dangerous times. Kirby drew him with strong echoes of the 1931 cinematic Frankenstein, giving him a rather square head and Karloff-esque fringe (see Figure 1) - a reference that was strengthened by naming one of Banner's colleagues Igor. ${ }^{44}$ The hubris of this technological advance was explicitly expressed when Igor challenges Banner for not following scientific norms and refusing to share his research with other scientists so it can be checked, to which Banner curtly replies, 'I don't make errors'. ${ }^{45}$ Inevitably, Banner gets caught in the blast while saving a teenager, Rick Jones, who trespassed onto the test site. As the gamma rays engulf his body, the caption reads, 'the world seems to stand still, trembling on the brink of infinity'. ${ }^{46}$ Banner then undergoes a transformation when the sun goes down and becomes The Hulk- 'that creature which fears nothing — which despises reason and worships power'. ${ }^{47}$ Yet, despite his strength, the creature's first instinct is to hide, wanting only to be left alone.

\footnotetext{
${ }^{35}$ Neuhaus, "Nihilism," 54.

${ }^{36}$ Neuhaus, "Nihilism," 54.

${ }^{37}$ Neuhaus, "Nihilism," 59.

${ }^{38}$ Neuhaus, "Nihilism," 59.

${ }^{39}$ Schmitt, Legality and Legitimacy, 28.

${ }^{40}$ Neuhaus, "Nihilism," 63.

${ }^{41}$ Neuhaus, "Nihilism," 62.

42 Neuhaus, "Nihilism," 62.

${ }^{43}$ Lee, Incredible Hulk \#1.

${ }^{44}$ This theme is further developed in naming Hulk's first enemy 'Golem', a reference to the antediluvian Frankenstein in Jewish myth.

${ }^{45}$ Lee, Incredible Hulk \#1, 3.

${ }^{46}$ Lee, Incredible Hulk \#1, 4.

${ }^{47}$ Lee, Incredible Hulk \#1, 14.
} 


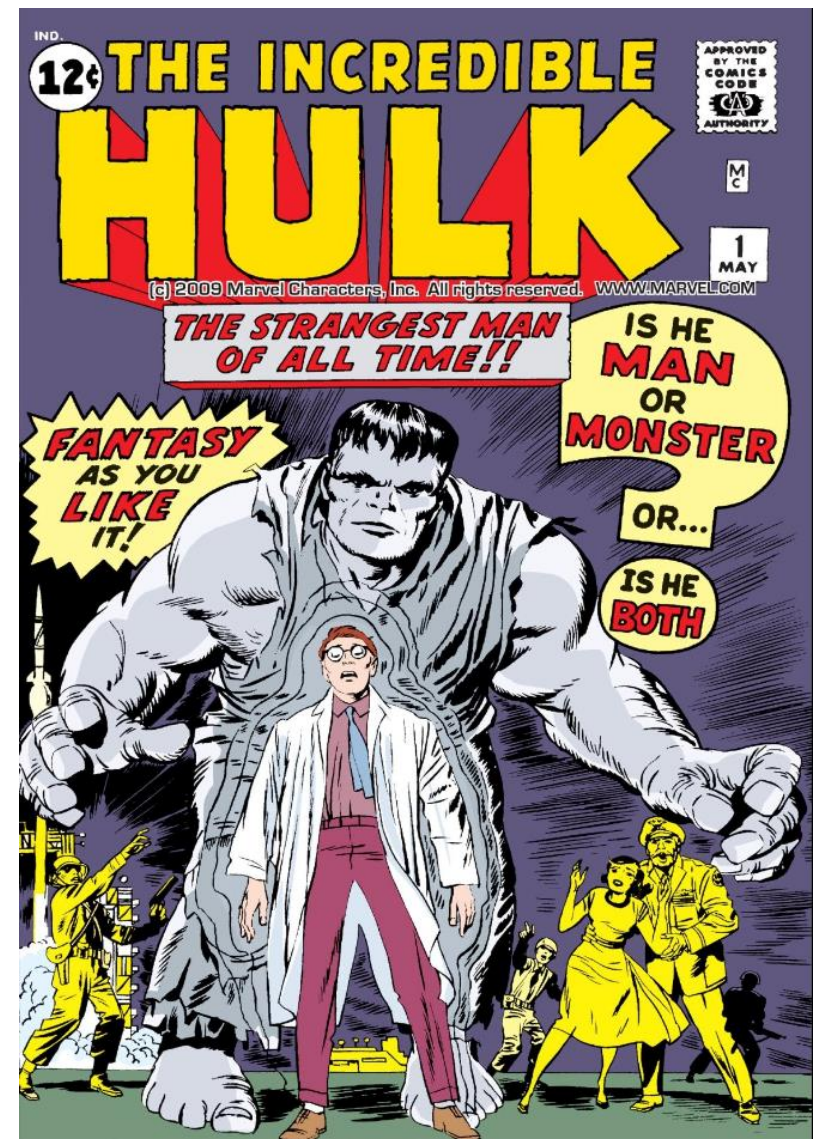

Figure 1. Cover art for Lee and Kirby's The Incredible Hulk \#1, 1962.

Image credit: Jack Kirby and George Roussos. The Incredible Hulk \#1. Ink and pencil. New York: @ Marvel, May 1962

This reworking of Mary Shelley's Frankenstein; Or, the Modern Prometheus became one of Marvel's most popular characters; although, it took two years for Lee to fully conceptualise Hulk as the man who turned into a monster when angered ${ }^{48}$ In this change he not only continued to epitomise the dangers of technology and our desire to control the unlimited forces of creation, but was also now the embodiment of the hostility that underpinned the development of weapons of mass destruction and a malice of which anyone, in their own way, is capable. Although Prometheus appeared in The Incredible Hulk \#368 from 1990 as part of a group called Pantheon, it was not until Peter David's story The End in 2002 that The Hulk himself was explicitly presented as the mythical titan. ${ }^{49}$ Prometheus is known as the creator of the human race and the being who stole fire from the gods. In return, Zeus created Pandora and introduced her to Prometheus's brother, Epimetheus. She brought a jar with her containing numerous evils, and once opened the evils plagued humans as punishment for Prometheus's transgression. Prometheus himself was then chained to a rock and birds pecked at his liver, which continually regenerated, creating a potentially eternal punishment.

In the story written by David and drawn by Dale Keown we are introduced to a 200 -year-old Bruce Banner. He is alive because The Hulk — who at this point in the character's development had become indestructible, if not actually immortal—will not let him die. Primarily, this is because 'Hulk hates Banner', ${ }^{50}$ particularly his weakness, and wants him to suffer. We learn that after a global war Banner/The Hulk is (are) the only one(s) left alive. In the form of Banner, the scientist wryly notes how technology helped to defeat all enemies except for 'the one enemy humans were helpless before: other humans' ${ }^{51}$ —and, we might add, their desire for the 'bad infinite'. While Banner laments the terrible work of global annihilation wrought by humans, we learn that The Hulk cares nothing for nuclear holocaust. He cares only about 'being the strongest one there is and being left alone'. ${ }^{52}$

\footnotetext{
48 This was introduced in Tales to Astonish \#59 in September 1964.

49 'Prometheus' was also the title of an episode of the television series (Series 4, Episode 1), which aired in 1980.

${ }^{50}$ David, The End.

${ }^{51}$ David, The End.

52 David, The End.
} 
The only other things to survive the apocalypse are cockroaches that now move in giant swarms. We see The Hulk devoured by one such swarm, only for his healing factor to kick in and regenerate his body. As Banner meditates on this process he has an epiphany and describes The Hulk as the 'heir to Prometheus. The living symbol of nuclear fire, to be devoured over and over again, but always to rise up and be consumed once more. ${ }^{53}$ Banner recounts the story and the theft 'from which flowed man's technology and scientific advancement', ${ }^{54}$ concluding that:

The Hulk was ... is ... the living symbol of the Atomic Age. The Atomic Age Frankenstein, they called him. The Atomic Age Jekyll and Hyde. The Atomic Age which brought fire and terrible, terrible knowledge for which the final, terrible price was ... oblivion. ${ }^{55}$

In the end, tired of Banner's constant musings and his attempts to kill himself, The Hulk decides to never let him out again, never to relinquish his personality to Banner's.

Prior to this we are told that Banner misses his friends and wider society. This is Banner's real weakness according to The Hulk. By contrast, The Hulk tells us he 'must never be weak. Never. Because ... Hulk is the strongest one there is. Hulk is only one there is. ${ }^{56}$ There is already a contrast here between a society of incomplete dependent beings and sovereign completeness of the strongest one. In the end, other people for The Hulk are both a risk and a limitation, which takes us back to Flahault's analysis of our desire for limitlessness. Commenting on our need to exist socially, Flahault writes:

\begin{abstract}
our fundamental propensity to exist as a complete whole clashes with the fact that in order to exist, we must exist in the mind of at least a few other people; we need to occupy a defined place in a shared world. ... So, doomed to incompleteness and the hazards of dependency, we strive by every possible means to escape the walls of our prison. ${ }^{57}$
\end{abstract}

This is precisely the tension between the law and Law. In this story, then, the monstrosity of The Hulk-as in what The Hulk shows us (monstrum) - is not simply the dangers of our desire to transcend limits through the use of technology. He also represents the desire to exist without relation: the desire to be absolute. However, the whole point of The Hulk is that he is not the perfect One of self-creation but the chaotic Nought of destruction and oblivion. He is the terrible thing that lies on the other side of the door. He is what the doorkeeper is protecting us from by resisting our desire to experience its completeness.

\title{
The Immortal Hulk and the One Below All
}

In Al Ewing's The Immortal Hulk \#1 the warnings are no longer enough and he takes us directly behind the door to get a glimpse of the Law we so desire. However, for Ewing, if we follow the logic of The Hulk, our search for the absolute does not lead us to the heavenly being that founds all law, but takes us straight to hell. To understand this, The Hulk's path in this story needs to be set alongside two others. The Hulk's own story begins with a crime, a murder that he avenges, only to begin his journey into the duality of his identity and the depths of his power. The second story belongs to his father, Brian Banner, whose attempts to assert his own despotic rule on the Banner family has for a long time been seen as the source of so much of The Hulk's anger and appetite for destruction. The third story is that of General James Fortean, leader of a government black ops team seeking to capture The Hulk for the purpose of weaponising his abilities, and whose love of order epitomises the Schmittian, extra-legal logic of sovereign power. Here, I will focus on these three paths as a means of navigating this very complex story.

Ewing's Hulk, like the original, transforms at night: the night is his time. Compared to Banner's world of reason and rationality, Hulk's world is that of intuition, mysticism and magical thinking. This brings to mind what Thomas Giddens calls the " "other scene" of law that the conscious order represses ${ }^{58}$ If The Hulk's realm is the world of myth, the dark underbelly of science, it is also the realm of the violence and world-breaking that Robert Cover argued the law disavows. ${ }^{59}$ In Issue 6 of The Immortal Hulk we are introduced to the central metaphor in the story. We learn that the original experiment with the Gamma Bomb opened access to another dimension, a portal known as the Green Door ${ }^{60}$ The door is also referred to in Issue 4 when Walter

\footnotetext{
53 David, The End.

54 David, The End.

55 David, The End.

56 David, The End.

57 Flahault, Malice, 70.

${ }^{58}$ Giddens, On Comics, 7.

${ }^{59}$ Cover, "Violence and the Word," 1603.

60 This concept was first introduced in Avengers \#684 when The Hulk once again returned from the dead.
} 
Langkowski comes looking for Bruce Banner. ${ }^{61}$ We learn that in Langkowski's own experiments to capture this unlimited power-experiments that turned him into the gamma-irradiated entity known as Sasquatch-he, too, opened the Green Door. We are also told that something possessed Langkowski at this point, a beast he calls Tanaraq. Langkowski is killed in a bar fight in Issue 4, but like The Hulk he returns as the Sasquatch once night falls. ${ }^{62}$ In the form of the Sasquatch he embarks on the inevitable rampage in Issue 5 and The Hulk intervenes to stop him, only to discover that the source of Langkowski's rage is not the Tanaraq, as he had assumed, but the spirit of Bruce's dead father, Brian Banner, which has made its way across the threshold of the open door. ${ }^{63}$ In absorbing all the gamma radiation from Sasquatch to stop him, The Hulk himself becomes possessed by the spirit of his father, the significance of which will be revisited.

To get rid of the thing possessing him, The Hulk goes back to the site of the first experiment where he believes he is strongest. However, he quickly realises that this is not his plan at all but his father's, who has drawn him there because Brian Banner also considers the blast site his place of power. At the same time, James Fortean has also sent the Absorbing Man to the test site to take down The Hulk. In the ensuing battle, the Absorbing Man drains Hulk of his radiation only to overload and cause a massive explosion. It is this that fully opens the Green Door. Once open, everyone at the blast site immediately finds themselves on the other side of the door in a place we commonly call hell. Effectively, The Hulk's attempt to return to the site where he is most powerful and where he believes himself to be sovereign has only led to a catastrophic fall into even greater danger. The textual and visual schema Ewing sets up in Issue 12 are crucial to understanding this dynamic. He overlays this scene with a discussion of theology. He talks of the Qabalah, containing the Sephirot that make up the tree of life in Jewish mysticism, and their shadow, the Qliphoth, that represent evil and the dark forces of conflict and chaos. Alongside this he talks in dualistic terms of a creator, 'the maker of ineffable plans, who works only for our good. The mysterious and heavenly father. And against the father ... his monstrous ENEMY. The breaker-apart.' 64

In the images accompanying this text we see Brian Banner in the panel containing the caption, 'heavenly father', and a young Bruce in the panel with the caption, 'breaker-apart'. This scene, split across four pages, gives us the Epimethean view of The Hulk - the hindsight that allows us to see from where all the rage and hate has come. The scene depicts a moment in the Banner household where the cruel, scolding and demeaning words of his father prompt Bruce to destroy the toy world he has carefully created on the living room floor, and with that the vision he has of himself. His father's despotic imposition of the law and the refusal to recognise any limit to his authority leads to a profound moment of destruction. Later in the issue we go further back to the point of Bruce's birth and find that his father's violence is not simply about the desire to impose his authority as the source of law in the household so much as his own desire to transcend limits. We come to learn that Brian Banner only saw his son as an impediment and a barrier to his own desire for fulfilment. Bruce's arrival took away the love that Bruce's mother had previously directed solely at her husband. Unable to deal with this interruption to his sense of completion, he killed her. Ultimately, it is this path of rage, hate and malice chosen by Bruce's father, and that seemingly set Bruce on the inevitable course of becoming a monster, that takes The Hulk to the depths of hell. However, here, to match his father's evil, The Hulk can only go deeper into it and assume the persona of the One Below All, the opposite of the personification of God in the Marvel Universe known as the One Above All. This will be revisited shortly.

Both The Hulk's and his father's descent into the abyss of the bad infinite is matched in the story by what happens to General James Fortean. In another Epimethean issue (Issue 21), we can see how Fortean's course was set by his religious schooling that taught him his love for the Law. At Sunday school, Fortean is taught the biblical creation story. The minister asks the children what God did when he created light. The answer, he tells them, is create structure. In making the first rule he gave what was without shape a form. Before the law there was only 'a dark, ever-changing sea' ${ }^{65}$ The structure of this first rule separating light from dark is a gift: 'That's why', he continues, 'we respect the elders who give us structure. ... Why we respect and emulate our parents, our teachers ... our police officers ... our brave fighting forces. ${ }^{66}$ Thus, Fortean becomes a soldier and commits to combating the bad infinite that threatens to destroy that structure.

The issue in which this backstory takes place is also bookended by two extraordinary images that show how Fortean pursued the good infinite only to plunge into the bad infinite. It starts with an image of him seated on a giant chair inside a massive robotic suit (figure 2) that greatly expands his own strength and capacities. This he will use to protect himself while retrieving the shell of another gamma-irradiated monster known as Abomination, which he wants to use to take down The Hulk. The text accompanying the image reads, 'for my country I have become ... a commander of shadows. But even in the shadows, there

\footnotetext{
${ }^{61}$ Ewing, Immortal Hulk \#1.

${ }^{62}$ Ewing, Immortal Hulk \#1.

${ }^{63}$ Ewing, Immortal Hulk \#1.

${ }^{64}$ Ewing, Immortal Hulk \#3.

${ }^{65}$ Ewing, Immortal Hulk \#5.

${ }^{66}$ Ewing, Immortal Hulk \#5.
} 
must be order. I am that order. ${ }^{67}$ At the end of the issue, entranced by the shell he has brought back, he cannot resist touching it. The shell of Abomination awakes and consumes him. At this point the text reads, 'I thought I was that order. I thought I could rule over chaos. I did not know what chaos was.' ${ }^{68}$ The issue then closes with an image of Fortean inside the shell and sat atop a very different throne (Figure 2). It is not long before he is dead.
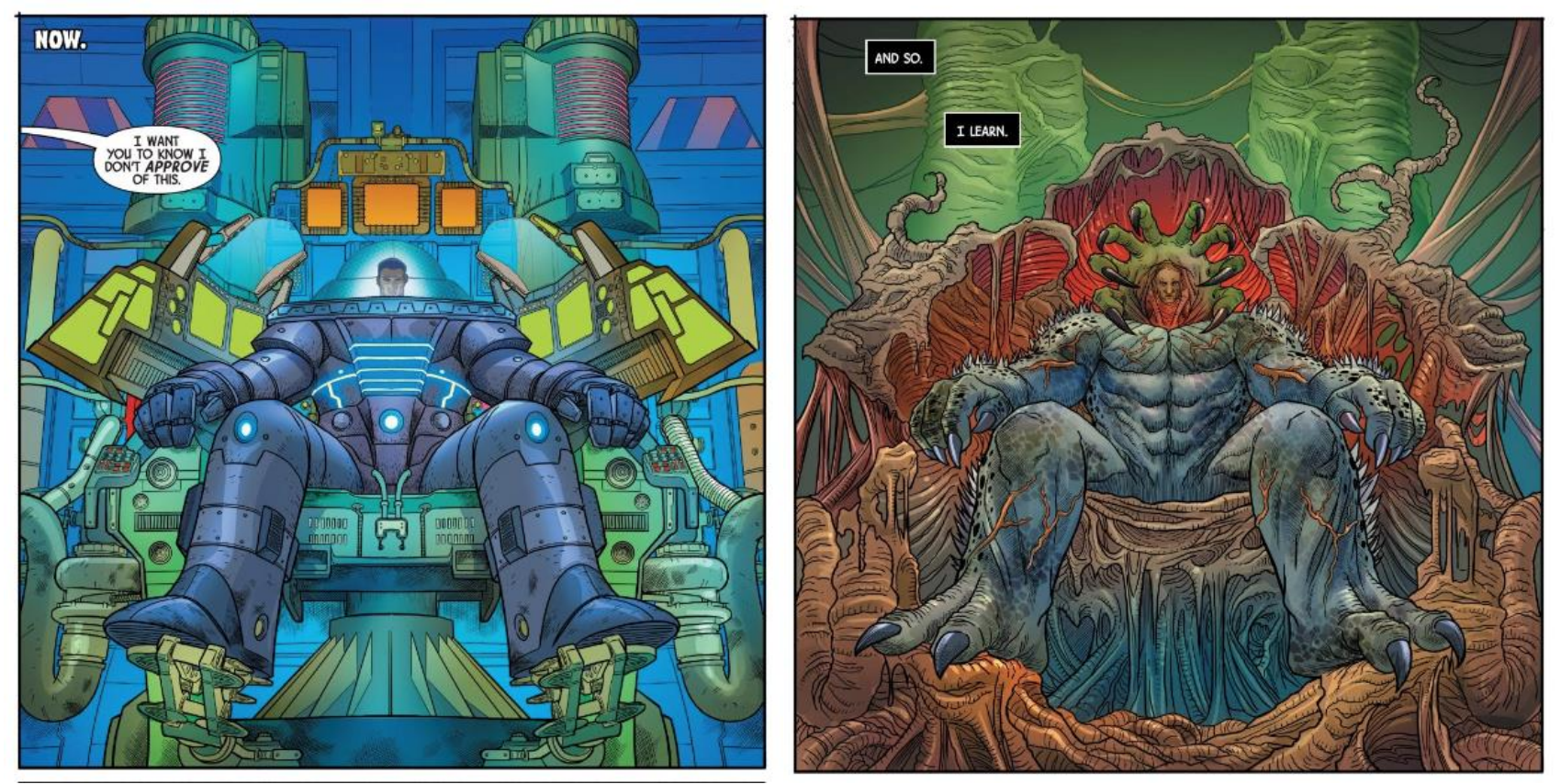

Figure 2. Fortean in (a) Immortal Hulk \#5 and (b) Immortal Hulk \#1, No. 21.

Image credits: (a) Joe Bennett, Ruy Jose (Illustrators) and Paul Mounts (Colourist). Immortal Hulk \#5: Breaker of Worlds. Ink and pencil. New York: Marvel, 20 November 2019; (b) Ryan Bodenheim and Paul Mounts (Colourist). Immortal Hulk \#1, no 21. Ink and pencil. New York: (C) Marvel, 17 July 2019.

Returning to Hulk as the One Below All, it is in this mode that the comic offers its most startling Promethean view, in the sense that Prometheus also represents foresight. It is also the moment of meta-commentary about how the pursuit of the good infinite leads to being consumed by the bad infinite. At the end of Issue 24 we jump an unimaginable amount of time into the future and to the end of all things. ${ }^{69}$ Just as Galan merged with the Cosmic Sentience at the end of his universe to become Galactus we see a rather skeletal Bruce Banner meeting the One Above All, who tells him they will merge — chaos and order, duality and unity - to become a new entity at the beginning of a new universe. Unfortunately, Banner then manifests as the One Below All and tells the One Above All, or 'God', that he will kill him like he has killed everyone else. He then proceeds to open a huge, abyssal mouth and swiftly eat him (Figure 3).

\footnotetext{
${ }^{67}$ Ewing, Immortal Hulk \#5.

${ }^{68}$ Ewing, Immortal Hulk \#5.

${ }^{69}$ Ewing, Immortal Hulk \#5.
} 


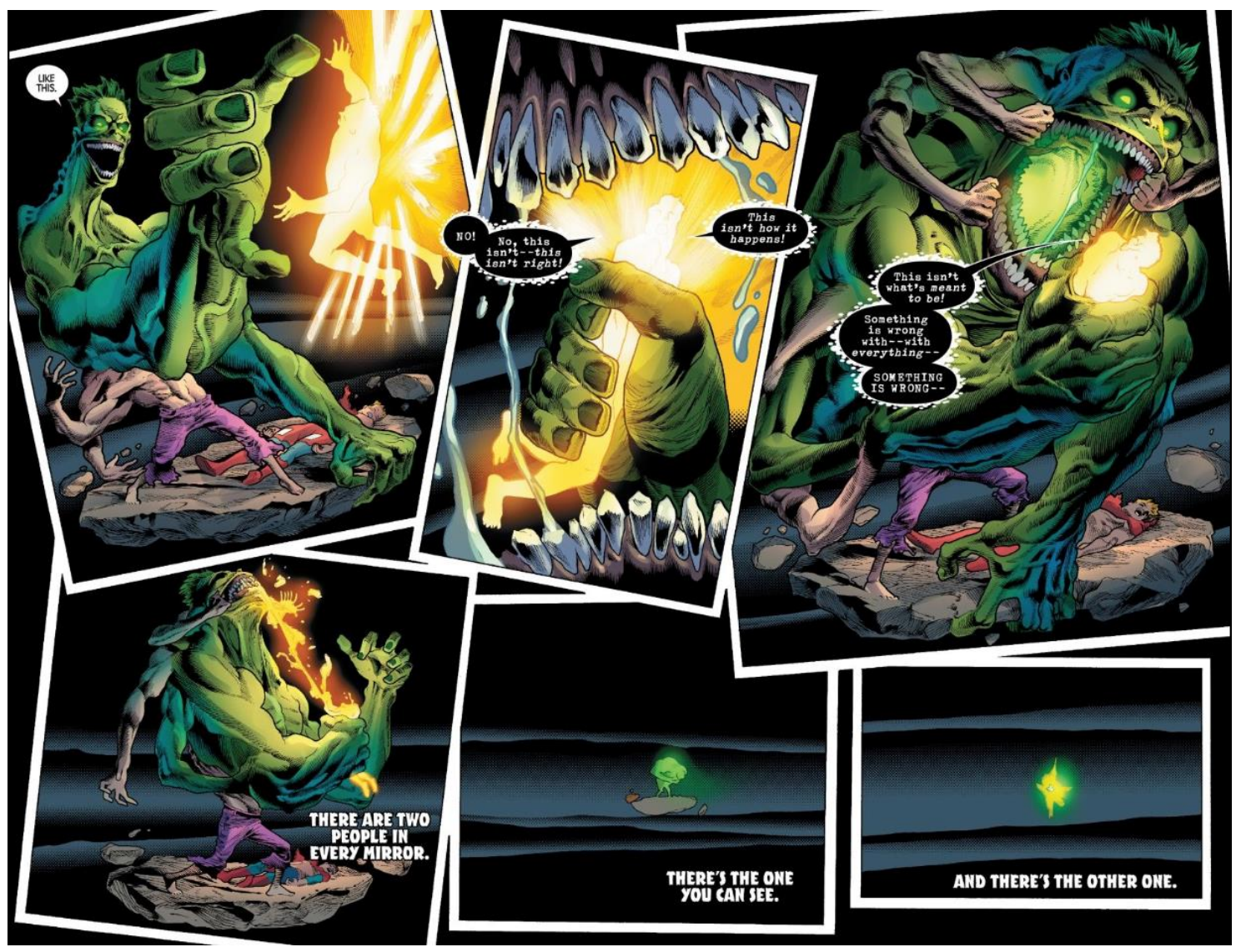

Figure 3. The Hulk consuming Galactus in Immortal Hulk \#5.

Image credit: Joe Bennett, Ruy Jose (Illustrators) and Paul Mounts (Colourist). Immortal Hulk: Breaker of Worlds. (Ink and pencil). New York: (C) Marvel, 20 November 2019.

This is evocative of another way Derrida has written about the Law that perfectly encapsulates the bestial nature of the allpowerful - at this point, sovereign-Hulk. While Hobbes's Leviathan made the direct comparison between sovereign power and biblical beast, ${ }^{70}$ Jacques Derrida shows how this comparison is another way of thinking about the Law's disturbing duality. ${ }^{71}$ Traditional theories, such as those by Jean Bodin, have always argued that the sovereign as a divine representative on Earth is not subject to the laws of the land but is separated from them as their source. ${ }^{72}$ In other words, the sovereign must be considered in some regard above the law. However, for Derrida, given that the beast is defined as less than human and, therefore, placed beneath the law, this means a certain 'being-outside-the-law'73 is common to both sovereign and beast, which is why they are so often pictured together. He expands by saying that:

sharing this common being-outside-the-law, beast, criminal, and sovereign have a troubling resemblance: they call on each other, ... from one to the other; there is between sovereign, criminal, and beast a sort of obscure and fascinating complicity, or even a worrying mutual attraction. ${ }^{74}$

He goes on to say - and this is especially true for superhero comics:

this resemblance ... makes us see, project, perceive, as in [an] X-ray, the face of the beast under the features of the sovereign; or conversely, if you prefer, it is as though, through the maw of the untameable beast, a figure of the sovereign were to appear. ${ }^{75}$

\footnotetext{
${ }^{70}$ Hobbes, Leviathan, 109.

${ }^{71}$ Derrida, Beast and Sovereign.

72 Bodin, Sovereignty.

${ }^{73}$ Derrida, Beast and Sovereign, 17.

${ }^{74}$ Derrida, Beast and Sovereign, 17.

${ }^{75}$ Derrida, Beast and Sovereign, 18.
} 
In a striking passage about sovereign violence that encapsulates the scene at the end of Issue 24 of The Immortal Hulk, Derrida writes, 'it's about mouth, teeth and tongue and the violent rush to bite, engulf, swallow the other, to take the other into oneself' ${ }^{76}$ He then continues with language highly redolent of Flahault's analysis of our own desire for limitlessness, suggesting that sovereignty's 'greatest force, its absolute potency' might 'be, in essence and always in the last instance, a power of devourment'. ${ }^{77}$

Still, in this far-flung future, having devoured the One Above All, The Hulk becomes Galactus-Hulk or the Breaker of Worlds and proceeds to bring about the death of the universe by destroying every form of life within it. Without the structure of the One Above All, The Hulk is pure entropy, pictured punching his way through planet after planet. As the Breaker of Worlds finally destroys everything to the point at which 'all life is broken', ${ }^{78}$ we see a bright, green light emanating from his eyes, suggesting a disintegration that begins in The Hulk's head as he, in turn, slowly collapses. As the last remaining entity of this universe, a strange creature called 'Par\%l' seeks to communicate with the Breaker of Worlds through something called a 'tidingfly'. We see the small fly approach the body of the Breaker of Worlds only to find a gaping abyss. When the fly gets closer, the Breaker of Worlds appears hollow and without a soul. All that is left now is the void of the One Below All. On the page turn we discover the abyss of the One Below All is actually the open neck of the now headless Hulk (Figure 4), and we are once again brought into Bataille's theoretical terrain.

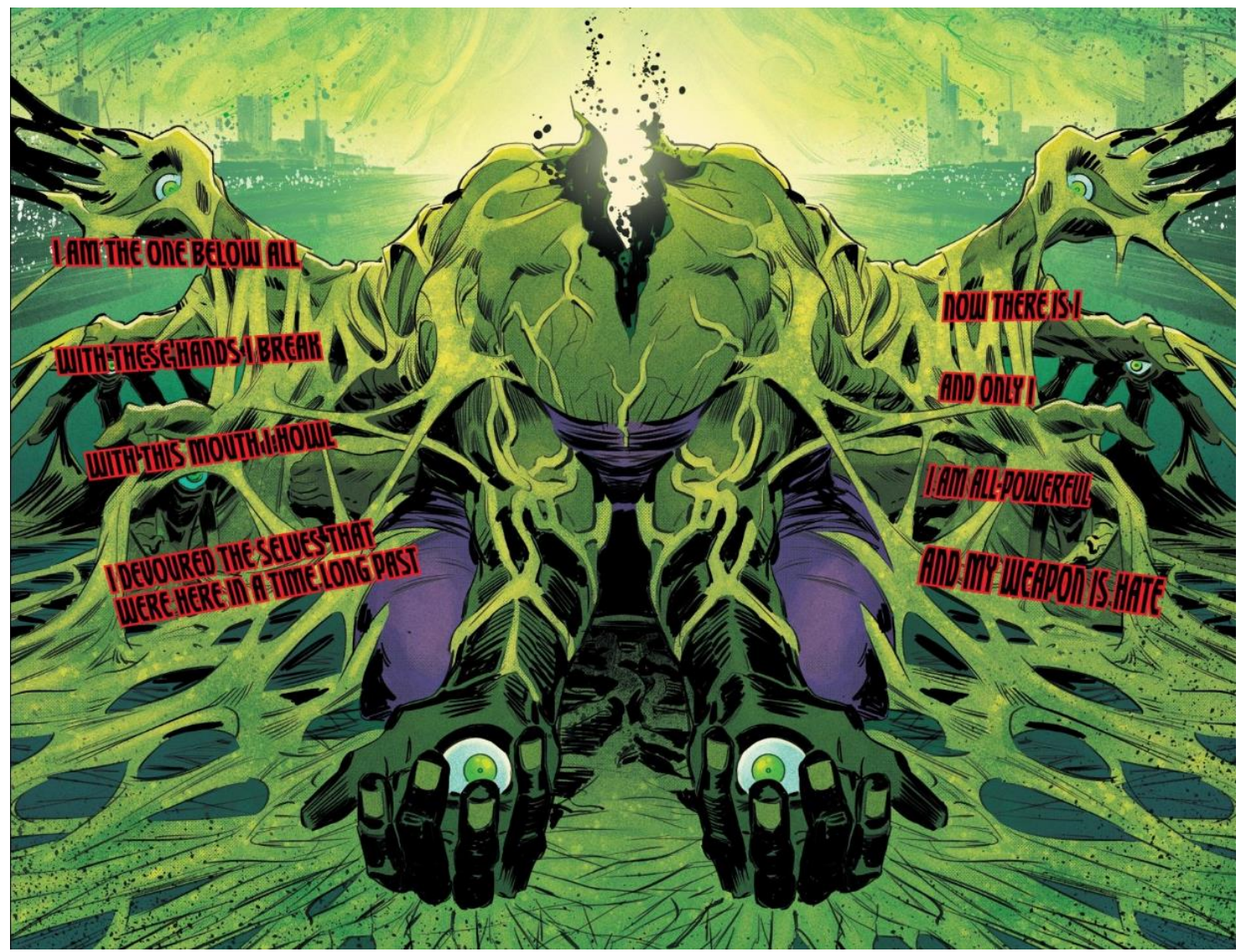

Figure 4. A headless Hulk in Immortal Hulk \#5.

Image credit: Germán García (illustration) and Chris O Halloran (colour). The Immortal Hulk: Breaker of Worlds. (Ink and pencil) New York: (c) Marvel, 2019.

\footnotetext{
${ }^{76}$ Derrida, Beast and Sovereign, 23.

${ }^{77}$ Derrida, Beast and Sovereign, 23.

${ }^{78}$ Ewing, Immortal Hulk \#5.
} 
It is well known that Bataille held a fascination for headless figures, even naming the review he founded, Acépahle, after such a mythic curiosity. In a seminar on Bataille's writings on Nietzsche, Bernard Harcourt explains the significance of the headless man as set out by Bataille in the second issue of Acéphale, published in 1937. Harcourt writes:

this headless man, Bataille believed, would point us both to the 'surhumain' (the superhuman) and to the death of God. L'acéphale, the headless man, Bataille would write in his essay 'Propositions,' is the mythic representation of 'the superhuman that IS fully death of God' . ${ }^{79}$

This perfectly encapsulates Bataille's view of sovereignty as a passage towards limitlessness in the company of death, and yet it also represents Flahault's fear that God and the good infinite is insufficient to satisfy our desire for limitlessness. In fact, the good infinite is just another limit. However, Ewing's headless Hulk shows us just how dangerous the search for limitlessness is. There is no transcendence here, only dissolution.

\section{To Conclude, without Completing}

While Ewing's Immortal Hulk paints an extraordinary picture of what being the most powerful means, and where the desire for sovereign completeness and being without limit can take us, the real brilliance of the story lies in the revelation that once they enter hell in Issue 10 this is not so much about moving to a new realm as it is the discovery that they had always been there. In other words, it is not that the desire to be without limit might take us down a dangerous path if we are not careful, it is rather that the desire itself $i$ already such a path. We only manage to convince ourselves otherwise through denial and disavowal and the regular news stories that perpetuate the belief that our abyssal violence is the work of the Good or God. Returning to Kafka's 'Before the Law', in our desire to touch or experience the Law understood as complete fullness - the perfect One-we are always already exposed to and in the grip of a limitless, annihilating Nothing. This is the true source of our compulsion to make the pilgrimage to the door. Perhaps, as his eyes were fading due to old age, the man from the country did not notice that the immortal light emanating from the doorway was green.

However, despite the nihilism of this story, Ewing does show us the way out. Yes, there is the creation of a new universe at the end of Issue 25 - the Ninth Reality or Cosmos in the Marvel Universe-but this endless cycle of destruction and creation clearly does not escape nihilism. ${ }^{80}$ Although Ewing's run on the comic was far from over at the time of writing, he had already indicated the way out of hell, and it is not the transcendent pursuit of the Law but the mundane realm of the social. For many years now, the story of the monster's twin personality, split between Banner and The Hulk, has become much more complex. As the many facets of Banner's childhood trauma have been revealed through analysis, the personalities in the monster might now be thought of as a collective. Therefore, The Hulk is a composite of the original Grey Hulk, the later Green Hulk, which became Savage Hulk. There is also a version of the Grey Hulk known as Joe Fixit, and a merged Hulk, known as The Professor, that allows the intellect of Banner and the strength of Savage Hulk to manifest simultaneously. In addition, there are manifestations of The Hulk linked to his father, Brian, which are malevolent representations of his childhood. These are Guilt Hulk and Devil Hulk. There is also, of course, the World-Breaker and the One Below All. This collectivity is even more pronounced when we include the assistance The Hulk receives from the wider gamma community during the story. This includes his original sidekick, Rick Jones; Hulk's perennial love interest, Betty Ross; Banner's psychiatrist, Doc Samson; and others with transformative abilities such as Walter Langkowski. However, this corporation does not form the unity of the sovereign in the sense understood by Thomas Hobbes. ${ }^{81}$ It is more like the 'heterogeneous assembly' that Bruno Latour calls a 'common collective'. ${ }^{82}$

The way out of this nightmare, then, is for each one of these characters to play their part and take their place, at different times and in different ways, for each to limit but also complement the other. In the search for ever-greater strength or power in the desire to be the One, Hulk can only be the Nought of destruction. With the assistance of the wider gamma family and the limits his own personalities placed on his most destructive tendency, The Hulk can stay this side of the door and his strength can be used for more prosocial purposes. Monsters have always been omens. This is the word's etymology. What this monster shows us, then, is that the dangers in our desire for limitlessness are rarely if ever satisfied by the good infinite. Instead, such a desire always plunges us willingly into the chaos of the bad infinite. In opposition to that desire is the limiting function of the social. Instead of the Law that promises limitlessness and completion, the sociality of the law maintains the responsibilities, obligations and dependencies of each limited and discontinuous being within a collective. No matter how much we might crave a transcendent Law, with all its supposed glory, light, power, authority and fullness, there is only the law, the place it secures for us, and the responsibilities it demands from us. We are an emerging, diverse collective that the law can only tentatively support.

\footnotetext{
${ }^{79}$ Harcourt, "Georges Bataille," para. 3.

${ }^{80}$ Ewing, Immortal Hulk \#5.

${ }^{81}$ Hobbes, Leviathan, 109.

${ }^{82}$ Latour, Pandora's Hope, 98.
} 
We are and always will be incomplete as individuals, societies and nations, and the law can only do good when it facilitates and protects this incompleteness.

\section{Bibliography}

Bataille, Georges. Inner Experience. Albany: SUNY Press, 1988.

—. The Accursed Share. Volume 1. New York: Zone Books, 1991.

- Theory of Religion. New York: Zone Books, 1992.

- Eroticism. London: Penguin Books, 2001.

Bodin, Jean. On Sovereignty. Cambridge: Cambridge University Press, 1992.

Castoriadis, Cornelius. The Imaginary Institution of Society. Translated by Kathleen Blarney. Cambridge: Polity Press, 1987.

Cover, Robert M. "Violence and the Word." Yale Law Journal 95, no 8 (1986): 1601-1630.

Curtis, Neal. Sovereignty and Superheroes. Manchester: University of Manchester Press, 2016.

David, Peter, Dale Keown, Joe Weems and Dan Kemp. Hulk: The End. New York, Marvel, 2002.

Derrida, Jacques. "Before the Law." In Acts of Literature, edited by Derek Attridge, 183-220. New York: Routledge, 1992. . The Beast and the Sovereign. Volume 1. Chicago: University of Chicago Press, 2009.

Ewing, Al, Joe Bennett, Leonardo Romero, Ruy Jose and Paul Mounts. The Immortal Hulk: Or Is He Both?. New York: Marvel, 2019.

Ewing, Al, Joe Bennett, Martin Simonds and Lee Garbett. The Immortal Hulk: The Green Door. New York: Marvel, 2019.

Ewing, Al, Joe Bennett, Ruy Jose, Kyle Hotz and Eric Nguyen. The Immortal Hulk: Hulk in Hell. New York: Marvel, 2019.

Ewing, Al, Joe Bennett, Ruy Jose, Paul Mounts and Alex Ross. The Immortal Hulk: Breaker of Worlds. New York: Marvel, 2019.

Flahault, François. Malice. Translated by Liz Heron. London: Verso Books, 2003.

Giddens, Thomas. On Comics and Legal Aesthetics: Multimodality and the Haunted Mask of Knowing. London and New York: Routledge, 2019.

Harcourt, Bernard E. '2/13: Georges Bataille'. 13/13 Nietzsche (blog), 17 September 2016. http://blogs.law.columbia.edu/nietzsche1313/2-13/.

Hobbes, Thomas. Leviathan. Indianapolis: Hackett Publishing, 1994.

Kafka, Franz. The Complete Novels. Translated by Edwin Muir. London: Vintage Books, 2008.

Lacan, Jacques. The Seminar of Jacques Lacan, Book III: The Psychoses, 1955-1956. London: Routledge, 2000.

Latour, B. Pandora's Hope: Essays on the Reality of Science Studies. Cambridge: Harvard University Press, 1999.

Lee, Stan, Jack Kirby and Paul Reinman. The Incredible Hulk \#1. New York: Marvel, May 1962.

Lee, Stan, Jack Kirby and Joe Sinnott. Fantastic Four \#48. New York: Marvel, March 1966.

Lee, Stan, Mark Gruenwald and Jack Kirby. Super-Villain Classics \#1. New York: Marvel, May 1983.

Martel, James. "Waiting for Justice: Benjamin and Derrida on Sovereignty and Immanence." Republics of Letters 2 , no 2 (2011): 158-172.

Morrison, Grant, J. G. Jones and Doug Mahnke. Final Crisis. New York: DC Comics, 2014.

Nancy, Jean-Luc. The Creation of the World, or Globalization. Albany: SUNY Press, 2007.

Negri, Anotonio. Insurgencies: Constituent Power and the Modern State. Translated by Maurizia Boscagli. Minneapolis: University of Minnesota Press, 1999.

Neuhaus, Richard John. "Nihilism without the Abyss: Law, Rights, and Transcendent Good." Journal of Law \& Religion 5, no 1 (1987): 53-63. https://doi.org/10.2307/1051016.

Pérez, George and Marv Wolfman. Crisis on Infinite Earths. New York: DC Comics.

Schmitt, Carl. Legality and Legitimacy. Durham: Duke University Press, 2004.

. Political Theology: Four Chapters on the Concept of Sovereignty. Chicago: University of Chicago Press, 2005. 